\title{
Close Relationship of Virulent Bacteriophages of Streptococcus salivarius subsp. thermophilus at Both the Protein and the DNA Level
}

\author{
By FABIEN PREVOTS, PURIFICATION RELANO, MIREILlE MATA* \\ AND PAUL RITZENTHALER \\ Centre de Recherche de Biochimie et de Génétique Cellulaire, CTBM-INSA, avenue de Rangueil, \\ 31077-Toulouse Cédex, France
}

(Received 24 April 1989; revised 5 August 1989; accepted 11 August 1989)

\begin{abstract}
Comparisons of 23 virulent phages of Streptococcus salivarius subsp. thermophilus were made based on morphology, host-range, structural protein analysis, DNA restriction patterns and DNA homology. All the phages had isometric heads (diameters $55-58 \mathrm{~nm}$ ) and striated tails (lengths 221-275 nm). The genome sizes ranged from 37 to $43 \mathrm{~kb}$. The electrophoretic profiles of the structural proteins were related, with at least two major bands of about 23 and $29 \mathrm{kDa}$ in common for all the phages except three, $\phi 80, \phi 96$ and $\phi 99$. These latter phages, which had a particular protein composition (main proteins of 29 and $40 \mathrm{kDa}$ ) and high DNA homology between each other, showed only a low DNA homology with the other phages. Extensive DNA homologies were demonstrated by Southern hybridization for all the other phages. All these results suggest a close evolutionary relationship between the phages.
\end{abstract}

\section{INTRODUCTION}

One of the primary causes of slow acid production by lactic acid bacteria during fermentations in the dairy industry remains lysis by bacteriophages. Physical and genetic studies of lactococcal phages have yielded useful information which, when combined with data on phage resistance mechanisms (Daly \& Fitzgerald, 1987; Klaenhammer, 1987), may result in improved ability to limit phage infection. Similar analysis of phages of Streptococcus salivarius subsp. thermophilus (formerly $S$. thermophilus), which have been poorly studied thus far, may contribute to limiting phage infections in fermentations using these bacteria.

The morphology of some bacteriophages of Streptococcus salivarius subsp. thermophilus has been described. All the phages examined can be classified in group B of Bradley (1967) and appear to be very similar, with isometric heads $(50-70 \mathrm{~nm}$ in diameter) and tails $200-300 \mathrm{~nm}$ long with small base plates (Reinbold et al., 1982). Variants with shorter tails have also been isolated (Accolas \& Spillman, 1979). Collar-like structures have not been detected, but a single thin tail fibre is often observed (Teuber et al., 1987).

In the present study, we have compared 23 virulent phages of $S$. salivarius subsp. thermophilus in respect of their host-range, morphology, protein composition, DNA restriction patterns and DNA homology.

\section{METHODS}

Bacterial strains and phages. All bacteria (S1 to S35) were Streptococcus salivarius subsp. thermophilus strains used in the dairy industry. The 23 phages ( $\phi 80$ to $\phi 102)$ were isolated in various French factories from yoghurt or cheese whey samples collected from abnormal fermentations over a period of several years. They all behaved as virulent phages.

Culture medium. All the $S$. salivarius subsp. thermophilus strains were grown at $40^{\circ} \mathrm{C}$ in $\mathrm{M} 17$ broth (Terzaghi \& Sandine, 1975).

Determination of host specificity of bacteriophages. The host range of each phage was determined by spot tests of phage dilutions: $10 \mu$ l of lysate or of appropriate dilutions was spotted onto $\mathrm{Ml}^{7} \mathrm{Ca}^{2+}\left(5 \times 10^{-3} \mathrm{M}^{-} \mathrm{CaCl}_{2}\right)$ agar plates previously poured in a double layer, the top layer having been inoculated with cultures of the strain tested. 
Phage purification and preparation of phage DNA. This was done as described earlier for Lactobacillus lactis bacteriophage $1 \mathrm{~h}$ (Trautwetter et al., 1986).

DNA-DNA hybridization. Phage DNA used as probe was labelled by nick-translation with $5^{\prime}-\left[\alpha^{-32} \mathrm{P}\right] \mathrm{dCTP}$ as described by Rigby et al. (1977) and Maniatis et al. (1982). Unlabelled phage DNA was digested with restriction endonucleases and the resulting fragments were separated by electrophoresis on a $1 \%(w / v)$ agarose gel. The Southern blot technique (Southern, 1975) was used to transfer restriction fragments onto BA-85 nitrocellulose filter sheets (Schleicher and Schuell). Hybridization was done at $65^{\circ} \mathrm{C}$ for $40 \mathrm{~h}$ in Denhardt reagent (Denhardt, 1966) as previously described (Mata et al., 1986). After hybridization, the filter was sequentially washed in: (1) $0.1 \%$ SDS/salmon sperm DNA [ $50 \mu \mathrm{g} \mathrm{ml}^{-1}$ in $1 \times \mathrm{SSC}(1 \times \mathrm{SSC}$ is $0.15 \mathrm{M}-\mathrm{NaCl}$ plus $0.015 \mathrm{M}$-sodium citrate $\left.)\right] / 1 \times$ Denhardt solution at $65^{\circ} \mathrm{C}$ for $1 \mathrm{~min}$ (four times) and for $45 \mathrm{~min}$ (three times); (2) salmon sperm DNA $\left(50 \mathrm{mg} \mathrm{ml} \mathrm{m}^{-1}\right) / 0.1 \% \mathrm{SDS} / 0.1 \times \mathrm{SSC}$ for $45 \mathrm{~min}$ at $65^{\circ} \mathrm{C}$ (three times); and (3) $3 \times \mathrm{SSC}$ for $10 \mathrm{~min}$ at room temperature (twice).

$S D S-P A G E$. Purified phage particles containing approximately $0.05 \mathrm{mg}$ protein were suspended in a solution containing $0.06 \mathrm{M}$-Tris $/ \mathrm{HCl}(\mathrm{pH} \mathrm{6.8)}, 5 \%(\mathrm{v} / \mathrm{v}) \beta$-mercaptoethanol, and $2 \%(\mathrm{w} / \mathrm{v})$ SDS, disrupted by boiling at $100{ }^{\circ} \mathrm{C}$ for $8 \mathrm{~min}$, electrophoresed as described by Laemmli (1970) and silver stained by the method of Oakley $\mathrm{et}$ al. (1980).

Electron microscopy of phages. Copper grids ( $3.05 \mathrm{~mm}, 400 \mathrm{mesh})$ were coated with carbon film. The phages were absorbed to the coated grids and examined in a transmission electron microscope (Jeol $1200 \mathrm{EX}$ ) at an accelerating voltage of $60 \mathrm{kV}$. Phages were photographed at $60000 \times$ magnification.

\section{RESULTS}

\section{Host-range determination}

The 23 phages ( $\phi 80$ to $\phi 102)$ were each purified by two successive single-plaque isolations on a lawn of a sensitive strain, and the resulting lysates were used to determine their host-range using 26 strains of $S$. salivarius subsp. thermophilus. From the data presented in Table 1, the

Table 1. Lytic pattern of the phages on some representative strains

Efficiency of plating of the following phages*

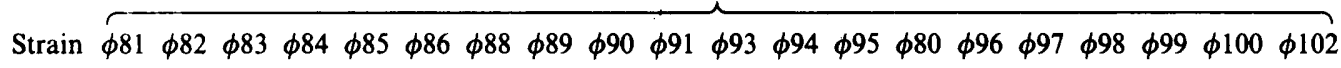

\begin{tabular}{|c|c|c|c|c|c|c|c|c|c|c|c|c|c|c|c|c|c|c|c|c|}
\hline S1 & + & + & - & - & - & $(+)$ & + & - & + & - & - & - & + & - & + & - & - & - & - & - \\
\hline S2 & + & + & + & + & + & + & + & + & $(+)$ & - & - & - & + & - & + & - & - & - & - & - \\
\hline S4 & + & + & + & - & + & + & + & + & + & - & - & - & + & - & - & - & - & - & - & - \\
\hline S7 & + & + & + & - & $t$ & + & + & + & + & $(+)$ & + & - & + & - & - & - & - & - & - & - \\
\hline $\mathrm{S} 12$ & + & + & + & + & + & + & + & - & + & - & - & - & + & - & - & - & - & - & - & - \\
\hline S15 & + & + & - & - & + & + & - & - & - & - & + & + & + & - & - & - & - & - & - & - \\
\hline S19 & + & + & $(+)$ & + & - & + & - & - & - & - & $(+)$ & - & + & - & - & - & $(+)$ & - & - & - \\
\hline S23 & + & + & - & + & - & + & + & - & + & - & - & - & + & - & - & - & + & + & - & + \\
\hline S28 & + & + & + & + & + & + & + & - & + & - & - & - & + & - & - & - & + & - & - & + \\
\hline S29 & + & + & - & - & + & + & + & + & - & + & + & - & + & - & - & - & - & - & - & + \\
\hline S30 & + & + & + & + & + & + & + & - & + & - & - & - & + & - & + & - & - & + & - & - \\
\hline S32 & + & - & + & - & + & + & + & - & - & + & + & + & + & - & - & - & + & - & - & - \\
\hline S33 & + & + & + & - & + & + & + & - & - & + & + & - & - & - & - & - & + & - & - & - \\
\hline S34 & + & + & + & - & + & + & + & - & + & + & - & - & + & - & - & - & - & - & - & - \\
\hline S35 & + & + & + & - & + & + & + & - & + & + & - & - & + & - & - & - & + & - & - & - \\
\hline S5 & - & - & - & - & - & - & - & - & - & - & - & - & - & - & + & - & - & + & - & - \\
\hline S6 & - & - & - & - & - & - & - & - & - & $(+)$ & - & - & - & - & - & - & - & - & - & - \\
\hline S16 & - & - & - & - & - & - & - & - & - & - & - & - & - & - & + & - & - & $(+)$ & - & - \\
\hline S17 & - & - & - & - & - & - & - & - & - & - & - & - & - & + & - & + & + & + & + & $(+)$ \\
\hline S18 & - & - & - & - & - & - & - & - & - & - & - & - & - & + & - & + & - & + & + & + \\
\hline $\mathbf{S} 21$ & - & - & - & - & - & - & - & - & - & - & - & - & - & - & - & - & - & + & - & + \\
\hline S24 & - & - & - & - & - & - & - & - & - & - & - & - & - & + & - & + & + & - & + & - \\
\hline S25 & - & - & - & - & - & - & - & - & - & - & - & - & - & + & - & + & + & - & + & - \\
\hline S26 & - & - & - & - & - & - & - & - & - & - & - & - & - & - & - & - & $(+)$ & - & - & - \\
\hline S27 & - & - & - & - & - & - & - & - & - & - & - & - & - & - & - & - & + & + & - & - \\
\hline S31 & - & - & - & - & - & - & - & - & - & - & - & - & - & - & - & + & + & + & - & - \\
\hline
\end{tabular}

- - , Absence of plaque formation; (+), efficiency of plating $<10^{-4} ;+$, efficiency of plating $>10^{-2}$ and $<10$. The efficiency of plating of a phage on a given strain is the ratio of the p.f.u. $\mathrm{ml}^{-1}$ on this strain to that obtained on the propagating strain. Phages $\phi 87, \phi 92$ and $\phi 101$, which were able to form plaques only on their propagating host, are not included in the table. 


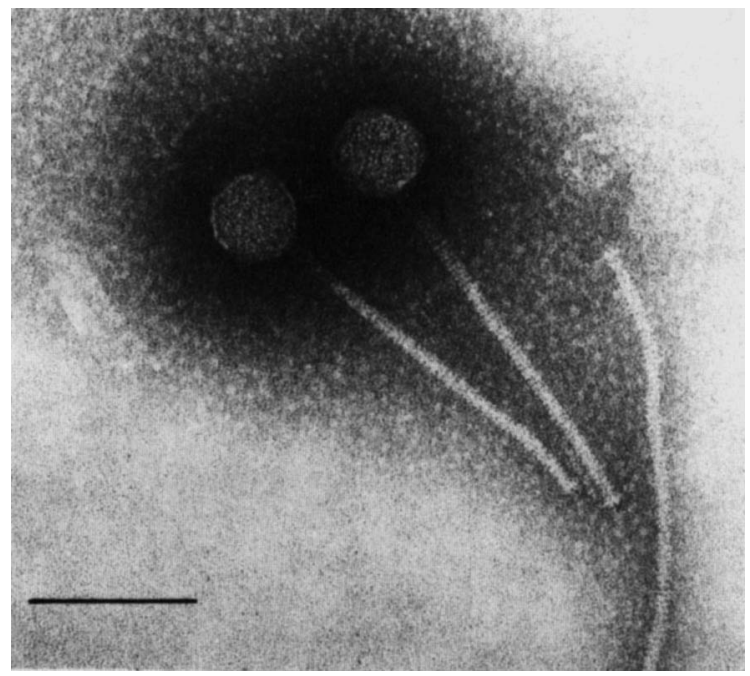

Fig. 1. Electron micrograph of phage $\phi 81 . \mathrm{Bar}, 100 \mathrm{~nm}$.

phages can be classified into two distinct groups. Lytic group I contains 13 phages ( $\phi 81$ to $\phi 86$, $\phi 88$ to $\phi 91$, and $\phi 93$ to $\phi 95$ ) which were unable to attack strains S5, S6, S16, S17, S18, S21, S24, S25, S26, S27 and S31 but showed some similarities in their host-range on the other strains. Lytic group II is composed of phages $\phi 80, \phi 96, \phi 97, \phi 98, \phi 99, \phi 100$ and $\phi 102$, which were able to propagate on at least three of the above-mentioned strains. In the two lytic groups, some phages have a narrow host-range $(\phi 80, \phi 89, \phi 94, \phi 100)$ and others have a wide host-range $(\phi 81, \phi 82$, $\phi 85, \phi 86, \phi 88, \phi 95)$; nevertheless each phage, except $\phi 81$ and $\phi 86$, has a specific host-range. Phages $\phi 87, \phi 92$ and $\phi 101$, which were able to attack only their propagating host, were not classified.

\section{Ultrastructure}

The morphology of the virulent phages was very similar to that described for other phages of $S$. salivarius subsp. thermophilus. All the phages had an isometric head (55-58 $\mathrm{nm}$ in diameter) and a striated tail (221-275 $\mathrm{nm}$ long and $8 \mathrm{~nm}$ wide) (Fig. 1). Occasionally, a thin fibre seemed to be attached to the terminal plate. As described by Reinbold et al. (1982), the phages showed a tendency to form phage clusters.

\section{Protein composition}

The structural proteins of purified phages were analysed by SDS-PAGE. Preparations of all the phages showed at least two intense bands, probably corresponding to the major proteins of the tail and the capsid, and other minor bands (Fig. 2). For each phage except $\phi 80, \phi 96$ and $\phi 99$, two intense protein bands approximating 23 and $29 \mathrm{kDa}$ could be detected; in addition to these major proteins, two common minor bands of 43 and $58 \mathrm{kDa}$ were also observed in some profiles. In the pattern of $\phi 80, \phi 96$ and $\phi 99$ the major protein of $23 \mathrm{kDa}$ was present but that of $29 \mathrm{kDa}$ was replaced by a $40 \mathrm{kDa}$ protein; the minor proteins were also specific to these phages. An additional intense band corresponding to a major protein of $26.5 \mathrm{kDa}$ could be detected in the pattern of $\phi 81, \phi 84$ and $\phi 85$; at the same position a band of weaker intensity also appeared in the protein patterns of $\phi 86$ and $\phi 95$. Whether the minor bands observed represent phage protein present in a low amount or were derived from the host bacterium is unknown, but the second hypothesis seems unlikely since the phages were purified by two successive caesium chloride gradients. 


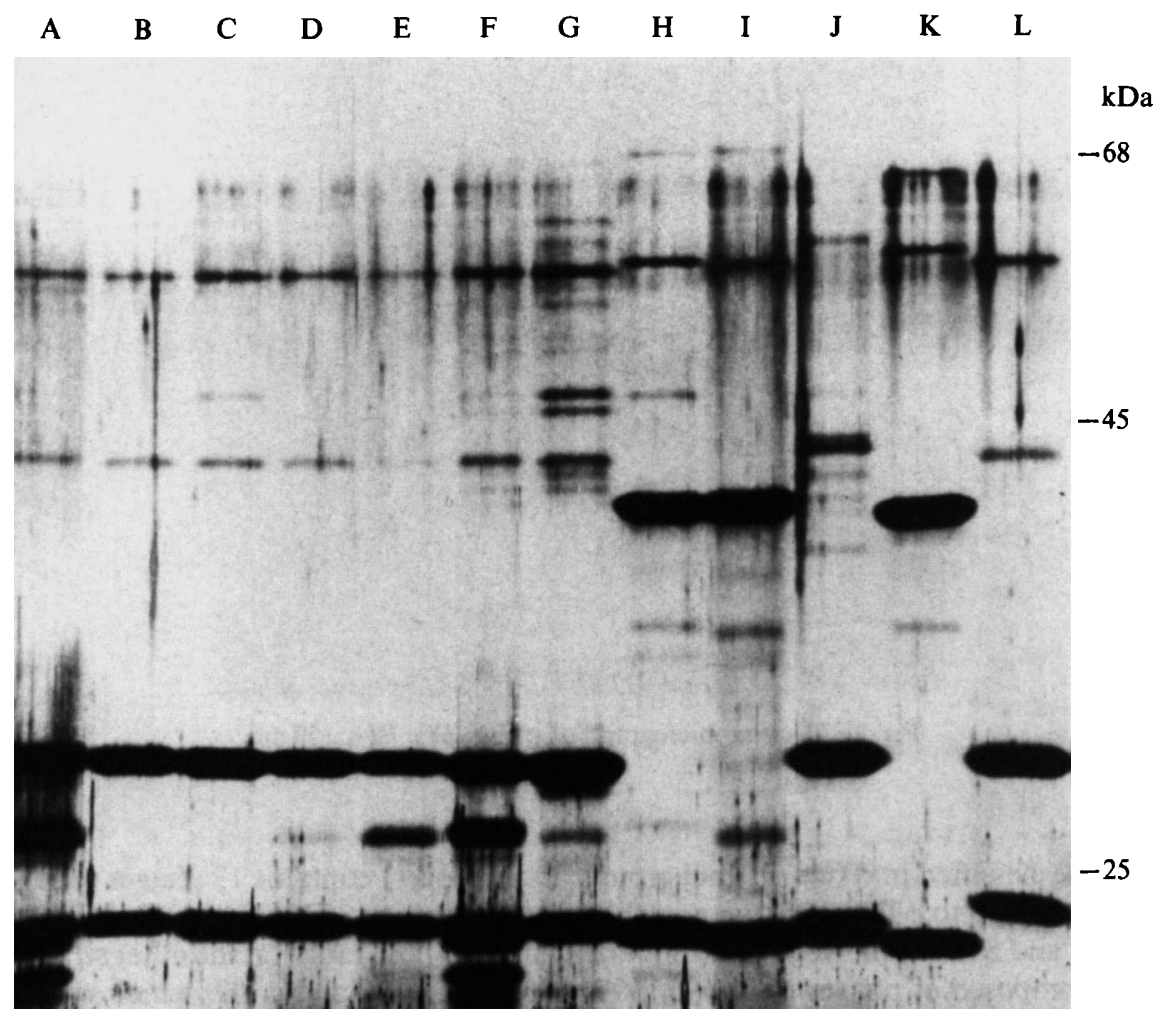

Fig. 2. Patterns of structural proteins of some of the phages by SDS-PAGE on $12 \%(\mathrm{w} / \mathrm{v})$ acrylamide gel. Lanes: A, $\phi 81$; B, $\phi 82 ;$ C, $\phi 88 ;$ D, $\phi 95 ; \mathrm{E}, \phi 84 ; \mathrm{F}, \phi 85 ; \mathrm{G}, \phi 86 ; \mathrm{H}, \phi 99 ; \mathrm{I}, \phi 96 ; \mathrm{J}, \phi 98 ; \mathrm{K}, \phi 80$; $\mathrm{L}, \phi 100$. Molecular mass markers (kDa): chymotrypsinogen A (25); hen egg white albumin (45); and bovine serum albumin (68).

\section{Comparison of restriction endonuclease patterns of the phage DNAs}

All the phages contained a double-stranded DNA molecule; the genome size of each phage was determined by summing the molecular sizes of restriction fragments generated by digestion with at least two endonucleases (EcoRI and $E c o \mathrm{RV})$. The estimated size of the different phage genomes ranged from 37 to $43 \mathrm{~kb}$. In EcoRV digestion (Fig. 3, Table 2), an identical restriction pattern with 12 DNA fragments was obtained for phages $\phi 81$ to $\phi 95$ except for phages $\phi 83, \phi 86$ and $\phi 89$, in which a fragment of $4 \mathrm{~kb}$ was absent and was replaced by a $3.4 \mathrm{~kb}$ fragment. All these phages belong to lytic group I ( $\phi 81$ to $\phi 95)$. Six fragments $(14,7,2 \cdot 2,1.65,1.3$ and $0.75 \mathrm{~kb})$ were detected when DNAs from these same phages were digested with EcoRI (Fig. 4, Table 3); an additional fragment of $12.2 \mathrm{~kb}$ appeared in the digests of all these phages except $\phi 83, \phi 86$ and $\phi 89$. The restriction pattern of these last three phages showed two additional fragments of 10.6 and $1.6 \mathrm{~kb}$ whose sum corresponds to the size of the $12.2 \mathrm{~kb}$ restriction fragment of the other group I phages. This result can be explained by the presence of an additional EcoRI site located in the $12.2 \mathrm{~kb}$ fragment. All the other phages (lytic group II) showed individual EcoRV and EcoRI restriction patterns.

\section{DNA-DNA hybridizations}

DNA homologies were detected by Southern blotting experiments. DNAs from $\phi 81$ (lytic group I) and $\phi 99$ (lytic group II) were labelled with [ $\alpha$-32P]dCTP by nick-translation and were used as hybridization probes to each phage DNA digested with EcoRI or EcoRV. The two probes hybridized to some or to the majority of the restriction fragments of the different phages, depending on the phage tested; the intensity of the signals also varied from phage to phage. 
$\begin{array}{lllllllllll}\text { A } & \text { B } & \text { C } & \text { D } & \text { E } & \text { F } & \text { G } & \text { H } & \text { I } & \text { J }\end{array}$

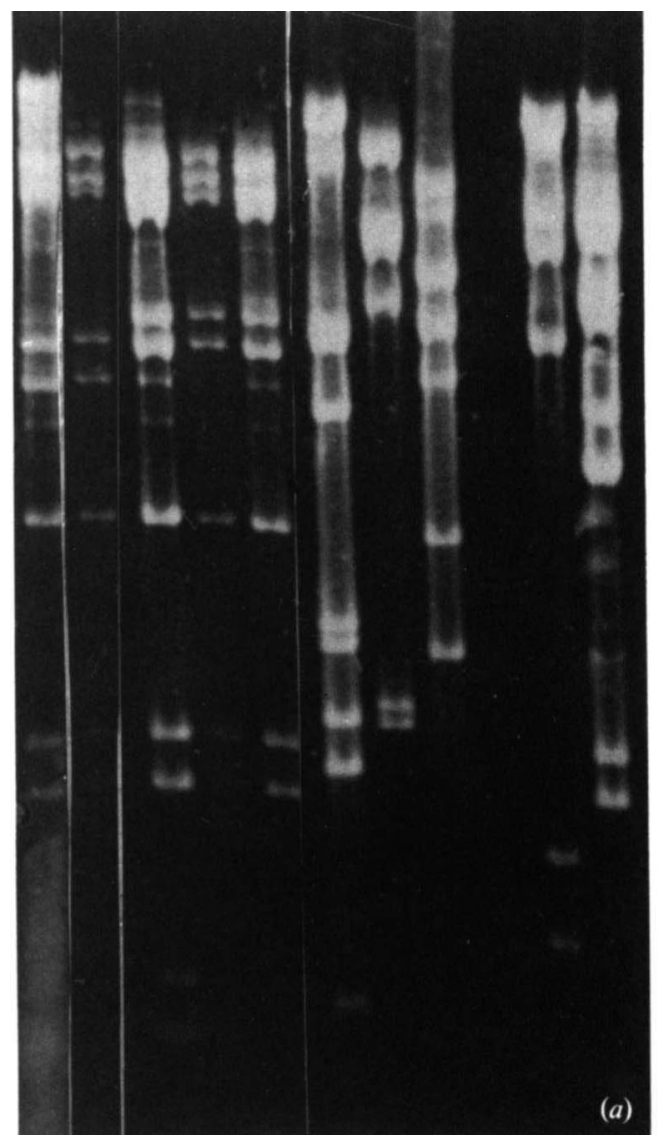

$\begin{array}{lllllllllll}\text { A } & \text { B } & \text { C } & \text { D } & \text { E } & \text { F } & \text { G } & \text { H } & & \text { I } & \text { J }\end{array}$

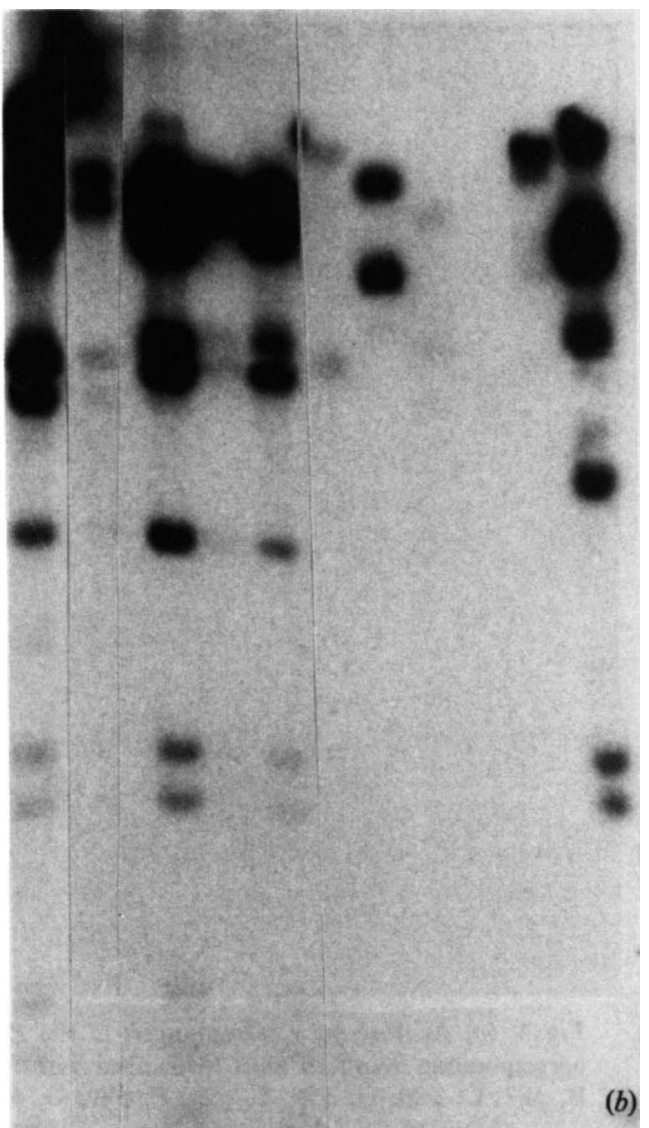

Fig. 3. (a) Agarose gel electrophoresis of EcoRV-generated fragments of phage DNAs; (b) the corresponding Southern blots hybridized with ${ }^{32} \mathrm{P}$-labelled DNA from phage $\phi 81$. Lanes: A, $\phi 83$; B, $\phi 89 ;$ C, $\phi 88 ; \mathrm{D}, \phi 95 ; \mathrm{E}, \phi 81 ; \mathrm{F}, \phi 96 ; \mathrm{G}, \phi 98 ; \mathrm{H}, \phi 99 ; \mathrm{I}, \phi 80 ; \mathrm{J}, \phi 100$.

Table 2. Homology between $\phi 81$ DNA probe and EcoRV restriction fragments of other phages

Phage

$\phi 81$ to $\phi 95$

(except $\phi 83, \phi 86, \phi 89)$

$\phi 83, \phi 86, \phi 89$

$\phi 98$

Size of restriction fragments $(\mathrm{kb})^{*}$

$\phi 100$

$\phi 80$

$\phi 96$

$\phi 99$

\begin{tabular}{cccccccccccc}
\multicolumn{10}{c}{ Size of restriction fragments (kb)* } \\
\hline 9.2 & 8 & 6.6 & 4 & 3.7 & 2.2 & 1.2 & 1 & 0.75 & 0.7 & 0.65 & 0.62 \\
+ & + & + & + & + & + & + & + & + & + & + & + \\
9.2 & 8 & 6.6 & 3.7 & 3.4 & 2.2 & 1.2 & 1 & 0.75 & 0.7 & 0.65 & 0.62 \\
+ & + & + & + & + & + & + & + & + & + & + & + \\
12 & 6.4 & 6.3 & 6.3 & 4.2 & 1.3 & 1.25 & & & & & \\
+ & + & + & + & $(+)$ & - & - & & & & & \\
13 & 6.6 & 6.1 & 4.2 & 3.4 & 2.8 & 1.2 & 1 & 0.65 & 0.62 & & \\
+ & + & + & + & $(+)$ & + & + & + & + & + & & \\
12 & 6.7 & 6.6 & 5.8 & 3.8 & 0.9 & 0.8 & 0.65 & & & & \\
+ & $(+)$ & $(+)$ & - & - & - & - & - & & & & \\
15 & 10 & 3.7 & 3.6 & 3.2 & 1.8 & 1.7 & 1.25 & 1.1 & 0.73 & 0.62 & \\
$(+)$ & - & $(+)$ & $(+)$ & - & - & - & - & - & - & - & \\
8 & 6.5 & 5 & 4 & 4 & 3.5 & 3.5 & 2.2 & 1.7 & & & \\
$(+)$ & - & - & $(+)$ & $(+)$ & - & - & - & - & & &
\end{tabular}

* + , Strong hybridization; $(+)$, weak hybridization; - , no hybridization. 


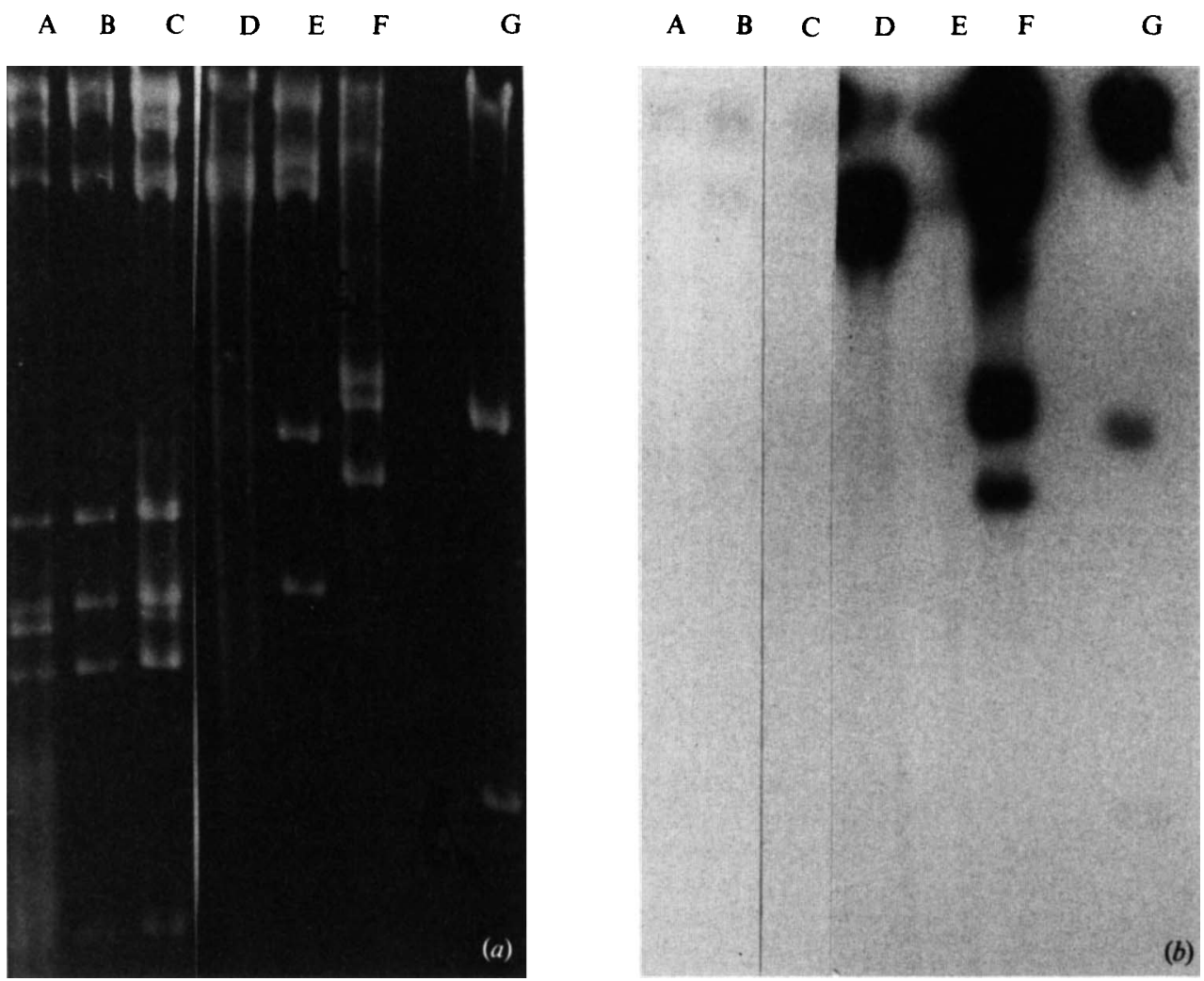

Fig. 4. (a) Agarose gel electrophoresis of the EcoRI-generated fragments of phage DNAs; (b) the corresponding Southern blots hybridized with ${ }^{32}$ P-labelled DNA from phage $\phi 99$. Lanes: A, $\phi 83$; B, $\phi 82 ;$ C, $\phi 86 ; D, \phi 96 ; \mathrm{E}, \phi 98 ; \mathrm{F}, \phi 99 ; \mathrm{G}, \phi 80$.

Table 3. Homology between $\phi 99$ DNA probe and EcoRI restriction fragments of other phages

\section{Phage}

\begin{tabular}{|c|c|c|c|c|c|c|c|c|}
\hline$\phi 81$ to $\phi 95$ (except $\phi 83, \phi 86, \phi 89)$ & $\begin{array}{c}14 \\
(+)\end{array}$ & $\begin{array}{l}12 \cdot 2 \\
(+)\end{array}$ & $\begin{array}{c}7 \\
(+)\end{array}$ & $\begin{array}{c}2 \cdot 2 \\
-\end{array}$ & $\begin{array}{c}1.65 \\
-\end{array}$ & $\begin{array}{c}1 \cdot 3 \\
-\end{array}$ & $\begin{array}{c}0.75 \\
-\end{array}$ & \\
\hline$\phi 83, \phi 86, \phi 89$ & $\begin{array}{c}14 \\
(+)\end{array}$ & $\begin{array}{l}10.6 \\
(+)\end{array}$ & $\begin{array}{c}7 \\
(+)\end{array}$ & $\begin{array}{c}2 \cdot 2 \\
-\end{array}$ & $\begin{array}{c}1.65 \\
-\end{array}$ & $\begin{array}{c}1 \cdot 6 \\
-\end{array}$ & $\begin{array}{c}1 \cdot 3 \\
-\end{array}$ & $\begin{array}{c}0.75 \\
-\end{array}$ \\
\hline$\phi 98$ & $\begin{array}{c}17 \\
(+)\end{array}$ & $\begin{array}{l}8 \\
-\end{array}$ & $\begin{array}{c}7.2 \\
-\end{array}$ & $\frac{3}{-}$ & 2 & & & \\
\hline$\phi 100$ & $\begin{array}{l}12.5 \\
(+)\end{array}$ & $\begin{array}{l}11 \cdot 5 \\
(+)\end{array}$ & $\begin{array}{c}6.9 \\
-\end{array}$ & $\begin{array}{c}4 \cdot 6 \\
-\end{array}$ & $\begin{array}{c}2 \cdot 3 \\
-\end{array}$ & & & \\
\hline$\phi 80$ & $\begin{array}{l}20 \\
+\end{array}$ & $\begin{array}{l}16 \\
+\end{array}$ & $\begin{array}{c}3.4 \\
(+)\end{array}$ & $\begin{array}{c}1 \cdot 1 \\
(+)\end{array}$ & & & & \\
\hline$\phi 96$ & $\begin{array}{c}18 \\
(+)\end{array}$ & $\begin{array}{r}8 \\
+\end{array}$ & $\begin{array}{l}8 \\
+\end{array}$ & $\begin{array}{c}6.7 \\
+\end{array}$ & & & & \\
\hline$\phi 99$ & $\begin{array}{l}18 \\
+\end{array}$ & $\begin{array}{l}9 \\
+\end{array}$ & $\begin{array}{c}3.7 \\
+\end{array}$ & $\begin{array}{c}3.4 \\
+\end{array}$ & $\begin{array}{c}2 \cdot 5 \\
+\end{array}$ & $\begin{array}{c}0.6 \\
+\end{array}$ & & \\
\hline
\end{tabular}

\footnotetext{
$*+$, Strong hybridization; $(+)$, weak hybridization; - , no hybridization.
}

The percentage of DNA homology between the probe and a given phage was calculated as the size of all the restriction fragments of the phage able to hybridize expressed as a proportion of the size of the entire phage DNA. This method gives an over-estimated value since partial hybridization between two fragments is sufficient to give a signal on the autoradiograms; 
nevertheless it enables an estimation of the homology between the phage DNAs. When $\phi 81$ was used as reference phage, the DNA homology was $100 \%$ for phages of lytic group I and about $80-90 \%$ for phages of lytic group II, except for phages $\phi 80, \phi 96$ and $\phi 99$ (Table 2). Only one or two restriction fragments of these three phages gave a weak signal when hybridized to the $\phi 81$ probe (Fig. 3). Conversely, $\phi 99$ DNA revealed homology of about $88 \%$ and $56 \%$ with $\phi 80$ and $\phi 96$ DNAs respectively, but gave only a few, weak signals when used as a probe with the restriction fragments of all the other phages of lytic groups I and II. In these cases, only the largest fragments were labelled (Fig. 4, Table 3). No hybridization was observed when representative phages of other species of lactic acid bacteria were used as probes : phage mv4 of Lactobacillus delbrueckii subsp. bulgaricus (Mata et al., 1986); $\phi \mathrm{T} 189$ and $\phi 936$ of Lactococcus lactis (Relano et al., 1987).

\section{DISCUSSION}

The majority of the phages of Streptococcus salivarius subsp. thermophilus analysed in this study showed a close relationship, demonstrated by their protein composition and by DNA-DNA hybridization experiments : their DNAs were able to hybridize at high stringency. In contrast, the phages could be classified into two distinct lytic groups. Phages belonging to lytic group I were very similar: they had analogous EcoRI and EcoRV restriction patterns and possessed two identical major proteins. Lytic group II was more heterogeneous: phages of this group had individual restriction patterns. Within group II, phages $\phi 98$ and $\phi 100$ possessed the two characteristic major proteins of lytic group I and their DNA hybridized strongly with the lytic group I phage DNAs. All the phages except $\phi 80, \phi 96$ and $\phi 99$ formed a single DNA homology group and were closely related. The differences observed in the host-range of the various phages do not involve large changes in the phage genomes since this criterion reflects the expression of only a small part of the phage genome. In previous work (Relano et al., 1987), it has been underlined that host range could not be correlated with molecular groups.

Phages $\phi 80, \phi 96$ and $\phi 99$ of lytic group II had two major proteins, only one of which was common to all the phages, the other being specific to these three phages. Their DNAs hybridized strongly with each other but showed weak homology with the other phage DNAs. Therefore they cannot be classified into a group completely separate from the main group, but they can be clearly differentiated into a subgroup.

Our results on restriction analysis contrast with those described in a preliminary report of Benbadis et al. (1987), in which 12 phages of Streptococcus salivarius subsp. thermophilus could be separated into two major groups with respect to their restriction patterns. In a study involving nine $S$. salivarius subsp. thermophilus phages isolated from Finnish cheese plants, Kivi et al. (1987) observed that the electrophoretic profiles of the structural proteins appeared nearly identical. The molecular masses of the four major proteins were estimated to be $63,49,42$ and $11 \mathrm{kDa}$. These protein profiles differed from our results, suggesting that these Finnish phages were different from those described here. In contrast, the phages of Streptococcus salivarius subsp. thermophilus described by Neve et al. (1989) seemed to have a protein composition similar to that of the phages analysed in this study: phages P6 and P8, with main proteins of 39.8 and $24.0 \mathrm{kDa}$, could be related to phages $\phi 80, \phi 96$ and $\phi 99$; and phages PO, PSt, P55, P53, 71/45 and $71 / \mathrm{St} 15$, with two major proteins of 30.9 and $24.0 \mathrm{kDa}$, could be related to all the other phages of this study. The latter group seemed to be the most widespread. The techniques used to characterize Streptococcus salivarius subsp. thermophilus phages in this study and Lactobacillus and Lactococcus phages in previous studies (Jarvis, 1984; Mata et al., 1986; Relano et al., 1987; Coveney et al., 1987; Lahbib-Mansais et al., 1988) have proved very useful in determining the relatedness between phages and have facilitated their classification into groups. For each bacterial species, phages could be classified into a small number of groups according to their DNA homology; within a family, the genes coding for the structural proteins seemed to be well conserved since at least the major proteins were common to all the phages of the group (Mata \& Ritzenthaler, 1988). 
The presence of non-homologous sequences flanked by homologous sequences in the phage genome probably plays an important role in phage evolution by permitting block DNA exchanges by homologous recombination between phages (Botstein, 1980).

This work was supported from grants from the Centre National de le Recherche Scientifique (LP 8201, Programme Biotechnologies). We thank M. A. Dupont and N. Gas for aid with electron microscopy, A. Belkhodja for her help during a stay in the laboratory and $\mathrm{N}$. Lindley for reading the manuscript.

\section{REFERENCES}

Accolas, J. P. \& SpIllman, H. (1979). Morphology of six bacteriophages of Streptococcus thermophilus. Journal of Applied Bacteriology 47, 135-144.

Benbadis, L., Faelen, M., Castellino, I., Fazel, A., Mercenier, A. \& Slos, P. (1987). Phages of Streptococcus thermophilus. FEMS Microbiology Reviews 46, (Abstracts) P43.

BotsteIn, D. (1980). A theory of modular evolution for bacteriophages. Annals of the New York Academy of Sciences 354, 484-491.

BRADLEY, D. E. (1967). Ultrastructure of bacteriophages and bacteriocins. Bacteriological Reviews 31, 230-314.

Coveney, J. A., Fitzgerald, G. F. \& Daly, C. (1987). Detailed characterization and comparison of four lactic streptococcal bacteriophages based on morphology, restriction mapping, DNA homology, and structural protein analysis. Applied and Environmental Microbiology 53, 1439-1447.

Daly, C. \& Fitzgerald, G. (1987). Mechanisms of bacteriophage insensitivity in lactic streptococci. In Streptococcal Genetics, pp. 259-268. Edited by J. J. Ferretti \& R. Curtiss, III. Washington, DC: American Society for Microbiology.

DENHARDT, D. T. (1966). A membrane filter technique for detection of complementary DNA. Biochemical and Biophysical Research Communications 23, 641-646.

JARVIS, A. W. (1984). Differentiation of lactic streptococcal phages into phage species by DNA-DNA homology. Applied and Environmental Microbiology 47, 343-349.

Kivi, S., Peltomäki, T. \& Sarimo, S. S. (1987). Some properties of Streptococcus thermophilus bacteriophages. Folia microbiologica 32, 101-106.

Klaenhammer, T. R. (1987). Plasmid-directed mechanisms for bacteriophage defense in lactic streptococci. FEMS Microbiology Reviews 46, 313-325.

LAEMMLI, U. K. (1970). Cleavage of structural proteins during assembly of the head of bacteriophage T4. Nature, London 227, 680-685.

Lahbib-Mansais, Y., Mata, M. \& RitzenthaleR, P. (1988). Molecular taxonomy of Lactobacillus phages. Biochimie 70, 429-435.

Maniatis, T., Fritsch, E. F. \& Sambroox, J. (1982). Molecular Cloning: a Laboratory Manual. Cold Spring Harbor, NY: Cold Spring Harbor Laboratory.
Mata, M. \& Ritzenthaler, P. (1988). Present state of lactic acid bacteriophage taxonomy. Biochimie 70, 395-399.

Mata, M., Trautwetter, A., Luthaud, G. \& RitzenthaleR, P. (1986). Thirteen virulent and temperate bacteriophages of Lactobacillus bulgaricus and Lactobacillus lactis belong to a single DNA homology group. Applied and Environmental Microbiology 52, 812-818.

NeVe, H., KrusCh, U. \& Teuber, M. (1989). Classification of virulent bacteriophages of Streptococcus salivarius subsp. thermophilus isolated from yoghurt and Swiss-type cheese. Applied Microbiology and Biotechnology 30, 624-629.

OAKLEY, B. R., KIRSCH, D. R. \& MORRIS, N. R. (1980). A simplified ultrasensitive silver stain method for detecting proteins in acrylamide gels. Analytical Biochemistry 105, 361-363.

Reinbold, G. W., Reddy, M. S. \& HAMmond, E. G. (1982). Ultrastructure of bacteriophages active against Streptococcus thermophilus, Lactobacillus bulgaricus, Lactobacillus lactis and Lactobacillus helveticus. Journal of Food Protection 45, 119-124.

Relano, P., Mata, M., Bonneau, M. \& RitzenTHALER, P. (1987). Molecular characterization and comparison of 38 virulent and temperate bacteriophages of Streptococcus lactis. Journal of General Microbiology 133, 3053-3063.

Rigby, P. W., Dieckmann, M., Rhodes, C. \& Berg, P. (1977). Labelling deoxyribonucleic acid to high specific activity in vitro by nick translation with DNA polymerase I. Journal of Molecular Biology 113, 237-251.

SOUTHERN, E. M. (1975). Detection of specific sequences among DNA fragments separated by gel electrophoresis. Journal of Molecular Biology 98, 503-517.

Terzaghi, B. E. \& Sandine, W. E. (1975). Improved media for lactic streptococci and their bacteriophages. Applied Microbiology 29, 807-813.

Teuber, M., KRusch, V., LuscheI, B. \& Neve, H. (1987). Isolation and characterization of virulent bacteriophages of Streptococcus salivarius subsp. thermophilus. FEMS Microbiology Reviews 46, (Abstracts) P42.

Trautwetter, A., Ritzenthaler, P., Alatossava, T. \& MATA-Gilsinger, M. (1986). Physical and genetic characterization of the genome of Lactobacillus lactis bacteriophage 11 h. Journal of Virology 59, 551-555. 